\title{
O duende de Töreby, de Selma Lagerlöf, seguido por Encontro com o homem cinzento, de Max Lundgren
}

Tobias da Rocha ${ }^{1}$

\section{Notas sobre o processo de tradução}

Eu li essas duas histórias muitas vezes ao longo dos anos, e especialmente "Encontro com o Homem Cinzento" tem um significado especial para mim desde a minha infância, quando a ouvi pela primeira numa fita cassete narrada pelo falecido ator Håkan Serner. Fiquei fascinado com a ideia dum fantasma amigável, que ainda assim tinha a capacidade de se ofender como um ser humano normal, e acho que isso também me ajudou a desenvolver uma espécie de compreensão - talvez também de simpatia - pelo velho homem enfadado que não suportava ser confrontado com um desafio que ia contra suas noções preconcebidas a respeito do mundo.

Ao se comparar estes dois contos, pode-se dizer que há muitos poucos sinais notáveis do uso do dialeto local, que no caso de Selma Lagerlöf era o dialeto de Värmland, e no caso de Max Lundgren, o dialeto de Skåne. Uma exceção notável seria que os personagens em "O Duende de Töreby" tendem a dizer "opp" em vez da versão moderna "upp" - ambos significando "para cima”.

Na história "Encontro com o Homem Cinzento" havia um pequeno número de expressões que eram realmente difíceis de expressar numa língua diferente.

1 Tobias da Rocha nasceu em São Paulo em 1985 e foi adotado para a Suécia, onde estudou português. Ouviu do ex-professor Ricardo Namora que parecia ter aptidão para a tradução e assim resolveu traduzir essas duas histórias. 
Por exemplo, a expressão usada para informar ao leitor que a porta da casa foi fechada pela neve seria mais ou menos traduzida como "nevar para dentro", o que naturalmente não faria muito sentido em português. Portanto, em vez de escrever que o homem cinzento "não nevou para dentro", optei por uma tradução mais compreensível: ele "não estava incomodado com a neve". As costas do homem cinzento também são descritas como "skulande" - uma palavra muito arcaica de Escânia que significa "procurar abrigo da chuva", e que até onde pude apurar significava que suas costas eram levemente curvas.

Outra expressão omitida foi "o céu tornou-se pesado como chumbo", o que significa que o céu tornou-se cinza-escuro pouco antes de a neve começar a cair novamente. Na mesma cena, quando o protagonista está andando na floresta, ele diz algo que se poderia traduzir diretamente como "eu andei dentro de meus pensamentos", o que significa que ele estava caminhando e pensando simultaneamente.

O avô se refere duas vezes à sua esposa como "kärringen", que no sueco moderno é considerado uma forma de tratamento pejorativa e ligeiramente ofensiva, mas originalmente veio simplesmente da palavra "kärling", significando mulher - a versão feminina da palavra "karl", homem.

Pode-se também notar que as palavras usadas para se referir aos avós na história original são "farmor" e "farfar", respectivamente, o que significa que eles são paternos e não maternos, o que, claro, não é imediatamente perceptível nem em inglês nem em português.

A história “O Duende de Töreby" foi escrita em algum momento nos anos antes da década de 1920, mas sua linguagem ainda é surpreendentemente moderna, embora contenha algumas frases um pouco antiquadas, que muitos leitores inexperientes do sueco considerariam difícil mesmo hoje. Alguns destes incluem "lock och pock", que significa "convencer por qualquer meio necessário"; "förmak" que normalmente significa o átrio do coração, mas que costumava significar uma antecâmara localizada na entrada duma casa ou apartamento, e "den lede", usado pelo cavaleiro para se referir ao capitão Duwe, que é um termo antigo para o diabo - literalmente, "o mal".

"Duende" talvez seja a tradução mais precisa da palavra "tomte" em sueco, que por sua vez é derivada da palavra "tomt", que geralmente significa uma área de terra adjacente a uma casa habitada. "Tomte" corresponde aproximadamente à palavra inglesa "leprechaun" e é usado também no sueco moderno para se referir ao Papai Noel. Eu achei interessante notar que enquanto a palavra "töre" (Töreby significa literalmente "A Aldeia de Töre") denota um pedaço de madeira de pinheiro contendo uma grande quantidade de seiva, "Töre" é também o 
nome de um personagem na trágica balada medieval chamada “Töres Döttrar I Wänge" ("As Filhas de Töre em Wänge”), que serviu de inspiração para o premiado filme de Ingmar Bergman chamado "Jungfrukällan", ou "A fonte da donzela" no Brasil.

Por fim, gostaria de agradecer a meu ex-professor Ricardo Namora da Universidade de Coimbra por sua ajuda na tradução dessas histórias. 


\section{Tomten på Töreby}

Selma Lagerlöf

Jag kommer ihåg att jag en gång som barn reste förbi en gammal gård, där man visste att det fanns en tomte. Gården låg mycket ensligt och fult på en flack sjöstrand. Det fanns ingen trädgård omkring det höga vita boningshuset, bara ett par förvuxna träd. Det var det tråkigaste ställe jag någonsin sett. Men det såg nog ut att vara en rik gård. Uthusbyggnaderna var välbyggda och stort tilltagna, och på åkrarna stod säden så frodig att jag kan minnas det än i dag.

Det märkvärdigaste var att se den ordning som rådde överallt. Jag minns, att vi körde långsamt förbi gården för att se hur väl dikena var grävda, hur rakt vägarna löpte och hur fast broarna var byggda. Vi lade märke till de nätta målade båtarna som gungade vid stranden, och till en ofantligt lång tvättbrygga som löpte rätt ut i sjön.

Det är väl tomten som vill att de ska skölja sina kläder ute på riktigt djupt vatten och inte i det grunda strandvattnet, sade vi.

Det var ingen som tvivlade på att allt var sådant det var där på gården för tomtens skull, eller att folket som bodde där trodde på honom. Det var av skräck för tomten, som det inte fick ligga kvar ett halmstrå eller en sticka på gårdsplanen, som lagården var putsad likt ett förmak och åkrarna var som trädgårdssängar.

Den där tomten hade funnits på gården i alla tider, och från alla tider fanns det historier om honom. Här ska jag berätta en, som torde ha tilldragit sig för omkring tvåhundra år sedan.

Det var en mörk höstnatt med regn som skvalade ner utför de gråa timmerväggarna, ty på den tiden var herrgården varken brädfodrad eller målad, och med storm, som kom alla kvistarna på den höga vildapeln vid gaveln att piska mot takåsen.

Mittunder det värsta ovädret kom en uggla flygande. Hon hade sitt bo uppe bland takstolarna på en av de stora vindarna och brukade flyga in dit genom en liten glugg tätt under takrännan. Men innan hon kunde hitta gluggen tog vinden fatt $\mathrm{i}$ henne, pöste upp hennes täta fjäderskrud så att hon såg ut som en rund boll, och kastade henne ett par gånger mot väggen. Då uppgav fågeln alla försök att komma in. I dess ställe satte den sig i vildapeln och skrek hela natten igenom.

Inne i byggnaden var det mycket tyst och stilla, men av ljusskenet, som silade ut genom springorna $\mathrm{i}$ fönsterluckorna märktes det att husfolket inte hade gått till sängs. En och annan gång hördes stoj och ett högt skratt, strax därpå blev det dödstyst på nytt.

Fram emot elvatiden på natten kom gårdens gamla hushållerska, som var fullt klädd och bar sina nycklar vid bältet som kunde hon inte skiljas från dem varken natt eller dag, ut i förstugan. Den tunga dörren var stängd med fyra olika lås, och det dröjde länge innan 
den gamla kvinnan kunde öppna den. Så snart hon hade fått den på glänt passade vinden på, svängde upp den på vid gavel, kastade en hel regndusch i ansiktet på hushållerskan och snurrade omkring bland trasmattorna i förstugan så att de slingrade som ormar.

Den gamla kvinnan stängde till dörren efter sig och vandrade ut i natten. Hon gick mycket fort som jagad av en stor förskräckelse, och mumlade oupphörligt :

Herren bevare oss! Herren bevare oss!

Hon lyste för sig med en hornlykta, men hon var så upptagen av att tänka på det som skrämde och ängslade henne att hon inte gjorde sig nytta av skenet, utan trampade ner i vattenpussar som hon väl kunde ha undvikit. Gång på gång vek hon i förvirringen av från den tilltrampade stigen, kom upp i gräsvallen och trasslade in sig i en törnhäck, som slet en flik ur hennes klänning. Allt detta tycktes hon inte märka. Hon fortsatte sin vandring oförtrutet allt under det att hon mumlade sitt :

Herren bevare oss! Herren bevare oss!

Äntligen kom hon fram till stallbyggnaden. Hon steg uppför loftstrappan, som liten och smal smög fram utanpå huset, och stannade vid luckan till höloftet.

Det glimtade ljussken innanför luckan, och när hushållerskan böjde sig framåt kunde hon se in i ett litet rum, vars väggar var behängda med selar, tömmar, sadlar och remtyg. Egentligen var det inte något rum, endast en avbalkning av höloftet. Höet pöste in genom de glesa brädväggarna, och mittpå golvet fanns en stor lucka genom vilken man kunde klättra ner till stallet. På en säng i ett hörn av kammaren satt den gamla gårdskusken. Han lyste för sig med en töresticka och läste i Guds ord. Han satt där, som hade han inte haft ro att lägga sig i det svåra ovädret. I varje ögonblick lyfte han huvudet från boken och lyssnade till storm och regn och uggleskri.

Hushållerskan knackade på och kusken kom och öppnade. Han började genast ursäkta sig för att han satt med bart ljus där på loftet. Han tycktes tro, att hon hade gått ut i natten endast för att be honom fara varsamt med elden.

-Jag vet nog att det är farligt, sa han, men jag tyckte det behövdes att någon läste ett Guds ord i denna natt.

Den gamla kvinnan svarade inte på detta. Hon satte sig ner på en lår som var full av läderbitar och järnskrot. Det var alltjämt en sådan skräck över henne att hon inte var vid sina sinnen, händerna slet i förklädet och läpparna rörde sig i ett ofattbart mummel.

Kusken satt och såg på henne, till dess att skräcken som tyngde henne också meddelade sig till honom. Det började darra i hans gamla matta händer och i hans tandlösa käkar.

-Har du kommit i möte med Gamle-far? frågade han viskande.

Gamlefar, det var tomten. Han gick aldrig under något annat namn där på gården.

-Nej, sa hushållerskan, och för Gamle-far skulle jag väl inte heller vara rädd. Han vill oss inget annat än gott.

-Du ska inte vara så säker på det, sa kusken. Han är allt en sträng herre, och på sista tiden har det nog hänt en hel mängd saker här på gården som han inte har tyckt om. 
-Om han vore så sträng som du tror skulle han väl inte låta ryttmästarn fara fram som han gör.

Kusken sökte lugna henne :

-Du får lov att tänka på att du talar om husbonden.

-Jag kan väl inte fördenskull låta bli att se, att han förstör både sig själv och gården, klagade hon.

-Det är ryttmästarn som är herre på gården. Vi är bara hans fattiga tjänare, upprepade kusken med viktig röst. Men plötsligen slog stämman över och han frågade med den yttersta ångest : Har han nu hittat på någon ny galenskap?

-Jag har stått vid salskammardörren hela kvällen och hört på hur han har spelat bort alla sina pengar, sa hushållerskan, i det hon satt och vaggade fram och åter med kroppen. När det blev slut med pengarna, spelade han bort hästar och kor. När det blev slut med djuren började han spela bort gården. Han sätter ut torp efter torp, skogsmark efter skogsmark, hage efter hage, åker efter åker och förlorar det alltsammans.

Kusken reste sig halvt upp från sin plats när han hörde detta, som ville han skynda ner och förhindra all denna ofärd. Men så satte han sig igen i en känsla av vanmakt.

-Det är ryttmästarn som är herre, sa han. Han kan göra vad han vill med det som är hans. Men jag kan inte förstå att Gamlefar inte blandar sig i spelet.

-Han håller alltid till här i stallet, han vet väl inte vad som händer inne hos oss, sa hushållerskan.

Det blev tyst en lång stund på loftet. Äntligen frågade kusken :

-Vem är det som spelar med honom i natt?

-Det är kapten Duwe, han som vinner, bara han rör vid tärningarna.

-Den karln är lika fattig på gods som på hjärtelag, sa kusken eftersinnande. Av honom kan ryttmästarn inte vänta någon barmhärtighet.

-Rätt nu äger han hela Töreby, sa hushållerskan.

Kusken tog upp bibeln, vände sig åt sidan för att komma i rätt dager och började läsa.

-Jag trodde att jag skulle förlora förståndet, medan jag stod och hörde på dem, sa hushållerskan, så hemskt var det. I början var de muntra, och vår husbonde skrattade åt allt vad han spelade bort. Men nu är de tysta, utom när vår ryttmästare har förlorat en ny åker. Då svär han, och den andre skrattar.

Den gamla kusken mumlade och läste, men han uttalade inga bibelord över hans darrande läppar kom ingenting annat än detta:

-Torp efter torp, skogsmark efter skogsmark, hage efter hage, åker efter åker.

-Vad hjälper det att du läser? sa hushållerskan. Om du vore något till karl, skulle du gå dit in och med lock och pock få honom att sluta, innan han har spelat bort hela gården.

-Jag har tjänat så länge på det här stället, att jag vet hur lätt det är att få en Silfverbrandt att sluta opp med någe, som han har kommit i gång med. Lika gärna kunde jag försökt väcka opp de döda. 
-Ja, nog borde detta vara tillräckligt för att väcka hans far och mor opp ur mullen, sa hushållerskan.

Kusken slog igen boken.

-Det är det värsta med hela saken, att han inte förstår att det inte går an att föra sådant liv på den här gården. Jag minns hur många gånger jag sa till hans salig far : "Ge inte Töreby till herr Henrik", sa jag, "han kan aldrig bli en herre efter Gamle-fars sinne. Ge det till hans bror, som är stadgad och allvarlig, och låt herr Henrik få en gård som inte medför ett sådant ansvar!"

-Ja, nu går inte Töreby varken till herr Henrik eller herr August. Nu går det till den där kapten Duwe, tills han spelar bort det till nån annan.

Kusken reste sig beslutsamt. Han knäppte tröjan och tog törestickan ur klykan. Det syntes tydligt, att hans mening var att gå och försöka tala med husbonden.

Men när han lyfte upp törestickan, kom han att hålla den så, att det föll ljussken över den fyrkantiga öppningen i golvet, genom vilken han plägade klättra ner till stallet. Och nu såg både kusken och hushållerskan, att det stod en tomte på stegen som stack upp genom hålet. Han stod på översta stegpinnen, liten och grå var han och klädd i knäbyxor och grå jacka med silverknappar. Han lyssnade med sådan bestörtning och häpnad, att han såg ut att ha blivit alldeles förstenad.

Kusken och hushållerskan vände genast bort blickarna. Ingen av dem gjorde en min, som visade att de hade sett tomten.

-Ja, nu tror jag det är bäst, att vi gamla människor går och lägger oss, sa kusken i en ton, som han sökte göra obesvärad. Du vet, att på den här gården behöver man inte sitta oppe om nätterna, också om olycka vore att vänta. Här finns den som vakar.

-Ja, du har rätt. Här finns en som vakar, sa hushållerskan undergivet. Utan ett ord vidare lyfte hon upp lyktan från golvet, kröp ut genom luckan och försvann utför loftstrappan.

När den gamla kvinnan kom tillbaka in i huset, var det hennes bestämda avsikt att genast gå till sängs, eftersom hon väl visste, att onödigt nattvak var det som tomten minst av allt kunde förlåta. Hon trodde också, att han skulle ställa saken till rätta, då han nu hade hört vad som stod på. Men hon hade knappast hunnit lägga av sig något mer än den tunga nyckelknippan, förrän hon greps av så stark lust att få veta hur det nu stod mellan de spelande, att hon åter smög sig fram till salskammardörren.

När hon böjde sig ner och satte ögat till nyckelhålet, såg hon att ryttmästar Silfverbrandt och kapten Duwe satt kvar vid spelbordet. Ryttmästaren såg förfärligt trött och matt ut. Hushållerskan tyckte, att han hade blivit alldeles förändrad på den lilla stund, som hon hade varit borta. Han var varken vacker eller ung eller ståtlig numera, utan bleknad och förstörd, med påsar under ögonen, rynkor i pannan och famlande händer. Duwe var röd i ansiktet, och ögonen stod blodsprängda ut ur huvudet, men han dolde all upphetsningen under godlynt prat och ett oupphörligt skratt. 
Hushållerskan hade inte lyssnat vid sals-kammardörren i två minuter, förrän Silfverbrandt sköt tillbaka stolen och utropa- de:

-Nu är det slut, Duwe. Nu har jag inte mer kvar av hela gården än tallholmen här ute i sjön. Den får du låta mig ha kvar, så att det finns något på jorden som jag kan kalla mitt.

Duwe skrattade, men han såg inte nöjd ut.

-Det är synd att bryta av spelet, sa han. När du har vågat allt det andra, så kan du väl också låta oss raffla om det där stenröset.

Silfverbrandt gick fram och tillbaka i rummet. Det syntes nog, att han ännu var besatt av spellusten. Han sörjde inte så mycket över att han hade förlorat allting, som däröver att han inte kunde fortsätta att spela.

-Vad sätter du opp emot holmen? frågade han.

Duwe betänkte sig ett ögonblick. Hushållerskan förstod, att han sökte finna ut en insats, som med säkerhet skulle förmå Silfverbrandt att fortsätta.

-Jag sätter opp din ridhäst, sa Duwe.

Silfverbrandt älskade sin ridhäst mer än något annat i världen. Han började svära alldeles förfärligt. Han frågade Duwe om han var den lede själv, eftersom han frestade honom på detta sätt.

Hushållerskan märkte, att var gång ryttmästaren under sin vandring kom till en mörk vrå av kammaren, så att Duwe inte såg honom, knöt han händerna i vrede.

-Det värsta är, att jag vet att jag kommer att slå ihjäl dig, när jag făr se dig rida på min häst och befalla på min gård, sa han till Duwe.

-Kan du inte unna en fattig karl att få det en smula sorgfritt på gamla dar? sa Duwe och skrattade. Du är ju ung och stark, du får dig snart både häst och gård på annat håll.

Hela tiden som hushållerskan hade stått där, hade hon undrat vad det stod på med den dörren, som från salen ledde ut i förstugan. Gång på gång öppnades den på glänt och slöts igen. Men varje gång Silfverbrandt gick förbi den där dörren, föreföll det som om en liten hand stacks in genom öppningen och vinkade åt honom.

Silfverbrandt gick förbi dörren flera gånger utan att märka något, men så blev han stående och stirrade på den.

-Nå, kommer du nu? frågade Duwe.

-Jag är tillbaka om ett ögonblick, sa Silfverbrandt och gick ut i förstugan.

Hushållerskan gled tyst som en skugga bort från salskammardörren. En sekund därefter stod hon inne i skafferiet med ansiktet tryckt mot ett litet fönster som vette ut mot förstugan.

Där stod Silfverbrandt lutad över tomten. Gamlefar höll en liten lykta i handen, och från den spreds en smula ljus i det mörka rummet.

-Vad ger du mig, om jag lagar så att du vinner igen gården? frågade tomten.

-Jag ger dig vad du vill, sa Silfverbrandt.

Tomten stoppade handen i fickan och tog fram ett par tärningar. 
-Om jag lånar dig de här tärningarna och du spelar med dem i natt, så tror jag nog att du vinner igen gården, sa han till Silfverbrandt.

Silfverbrandt sträckte ut handen.

-Ge hit! Ge hit! sa han.

Du får dem bara på det villkoret, att du i morgon spelar med mig om en insats som jag själv bestämmer, sa tomten.

Just i detta ögonblick skrek den stackars ugglan högt och hemskt. Silfverbrandt såg upp och lyssnade.

Den gamla hushållerskan märkte hur tomtens ögon började gnistra elakt och hat fullt. Hon ville slå in rutan och ropa åt sin herre att akta sig för att ingå något förbund med honom. Men i detsamma såg tomten upp mot henne med en fruktansvärd blick. Hon förblev stilla utan att våga röra ett finger.

Men även Silfverbrandt tycktes ha sett något fasansfullt hos tomten. Han drog till- baka handen och stod på väg att bege sig in i salen.

Så stannade han.

-Jag vet inte varför jag ska tro ont om dig, Gamlefar. Du har ju alltid haft stor omsorg om den här gården, sa han. Du vill mig nog inte något annat än gott. Ge mig då tärningarna! I morgon får det gå hur det vill, bara jag i natt kan göra Duwe lika fattig som han var när han i förrgår steg in i den här farstun.

Ögonblicket därefter var Silfverbrandt inne i salen.

-Nu sitter jag inte här längre och hör på ugglelåt och storm utan att få spela, utbrast Duwe. Nu går jag och lägger mig.

-Ska du inte först vinna av mig den där tallholmen? sa Silfverbrandt, i det han slog sig ner vid spelbordet.

Han tog upp den lilla bägaren, i vilken tärningarna låg, och skakade om dem. Sedan spelade han och Duwe i flera timmar, men Silfverbrandt vann i varje omgång. Under tiden avstannade ovädret, ugglan fann vägen in till sitt bo, den gamla hushållerskan måste för trötthets skull gå till sängs, men Silfverbrandt gick inte till vila förrän han hade vunnit tillbaka åker efter åker, hage efter hage, skogsmark efter skogsmark, torp efter torp, så att hela Töre-by åter var hans.

Det blev en präktig morgon efter den där ovädersnatten : hög, blå himmel, frisk luft och en speglande, klar sjö.

Den gamla hushållerskan blev kallad in till husbonden, medan han ännu låg.

När hon öppnade sängkammardörren, tyckte hon, att något, som var litet och grått skymtade förbi henne. Hon såg det bara så mycket att hon hann att rycka till. Så var det borta.

Ryttmästar Silfverbrandt låg mycket blek borta i sängen.

-Såg hon honom? frågade han. 
-Nej, sa hushållerskan av gammal vana. Det ansågs, att det inte var tomten angenämt, att man talade om att man hade sett honom.

-Det var Gamlefar, sa ryttmästaren. Han gick, just som hon kom. Han har varit här inne och spelat tärning med mig.

Hushållerskan stod och stirrade på husbonden.

-Gamlefar är inte riktigt nöjd med mig, sa ryttmästaren. Han vill hellre att min bror ska få gården. Och det önskar kanske hon också.

Ryttmästaren såg helt besynnerlig ut. Den gamla kvinnan visste inte vad hon skulle svara.

-Ja, gamle Duwe fick jag ändå bort från gården, fortfor Silfverbrandt. Jag hade tänkt löna Gamlefar för hjülpen med att låta det bli så här på gården som han vill ha det, men han har ingen rätt tro på mig. Han sätter opp så besynnerliga saker att spela om, den där tomten. Han är värre än Duwe.

Hushållerskan började darra och mumla som under natten :

-Herren bevare oss!

-Nå, stå inte där, människa, och se bekymrad ut, sa Silfverbrandt, utan skynda sig att putsa opp min uniform! Blanka opp bantläret, skura knapparna och ta ur fläckarna! Ridhästen ska också sadlas med den bästa munderingen. Manen ska vara kammad, stigbyglarna ska blänka och läderremmarna ska skina.

Hushållerskan såg förvånad på sin herre.

Hon gick och kom genast åter med uniformen. På en sådan gård som Töreby fanns ingenting som inte var putsat och fejat, blankat och välskött.

Så steg ryttmästar Silfverbrandt upp, iförde sig den blå uniformen, satte den trekantiga hatten till rätta på huvudet, band sabeln vid sidan och drog på sig de långa styva handskarna. Han gick ut på förstubron och sprang upp på sin häst, som väntade sadlad utanför.

Han red två gånger runtom gården, sedan svängde han av neråt sjön, där den långa tvättbryggan, som skjuter rätt ut från stranden, fanns redan på den tiden. Han såg så präktig och grann ut där han red, att allt husfolket kom ut för att se på honom. Och både kusken och hushållerskan såg, att tomten lutade sig ut genom stalluckan och tittade efter gårdens ägare.

När ryttmästaren kom ner till sjöstranden red han ut på bryggan. Han satt stolt och hög i sadeln som en hjälte, och hästen gick med korta dansande steg. När de hade ridit bryggan till ända, uppstod en kort strid mellan ryttare och häst. Hästen ville vända, men ryttmästar Silfverbrandt tvang honom med ridspö och sporrar att gå framåt. Och med ett högt språng kastade sig hästen ut $i$ vattnet.

Alla, som stod på gården, gav sig till att springa ner mot sjön. Men när de kom dit var både häst och ryttare försvunna. De hade gått till botten genast utan att komma åter upp till vattenytan. 
De unga karlarna hoppade i båtar och rodde ut på sjön. Alla talade och sökte ge råd och hjülp, men den gamla hushållerskan höll sig stilla.

Det tjänar ingenting till, sa hon. Det är tomten. Han har spelat bort sitt liv till tomten för den hjälp som han gav honom i natt.

Då människorna, bestörta och förfärade, vände tillbaka upp till gården, stod Töreby tomte synlig för alla i stalluckan och viftade segerstolt med sin röda mössa.

Ty nu visste han, att det åter skulle bli ordning och stillhet och allvarligt liv på Töreby. 


\section{O Duende de Töreby}

\section{Selma Lagerlöf}

Tradução do sueco:

Tobias da Rocha

Lembro-me de que uma vez, quando eu ainda era criança, passei durante uma viagem em frente a uma antiga fazenda onde se sabia existir um duende. A fazenda estava numa localização muito feia, na margem plana de um lago. Não havia nenhum jardim em volta da mansão alta e branca, apenas algumas árvores crescidas. Era o lugar mais chato que eu já tinha visto. Mas certamente a fazenda parecia rica. As instalações eram grandes e bem construídas, e os campos eram tão exuberantes que os recordo ainda hoje.

A coisa mais estranha foi ver como tudo estava perfeitamente em ordem. Me lembro de que passamos lentamente pela fazenda para ver como as valas haviam sido muito bem escavadas, como as estradas eram retas e como as pontes eram bem construídas. Percebemos os barquinhos pintados situados na margem do lago, e também um trapiche de lavagem incrivelmente longo que corria direto em direção o lago.

- O duende provavelmente quer que eles lavem suas roupas em águas profundas e não na margem do lago - dissemos.

Ninguém duvidava de que tudo era como era por causa do duende, ou de que as pessoas que ali viviam acreditavam nele. Era por causa do medo do duende que nem sequer uma única palha de feno ou uma lasca de madeira podia ser deixada no chão; o celeiro era limpo como uma antecâmara e os campos eram como espreguiçadeiras de jardim.

Esse duende estava morando na fazenda desde tempos imemoriais, e durante todo o tempo houvera histórias contadas sobre ele. Agora vou dizer-lhe o que afirmam ter ocorrido cerca de duzentos anos atrás.

Era uma noite escura do outono, e uma chuva caía sobre as paredes de madeira cinzenta - pois naquela época a mansão não era nem equipada com tábuas de madeira nem pintada -, uma tempestade que fez com que os ramos da grande macieira próximos ao frontão atingissem a cumeeira do telhado.

No meio da tempestade, uma coruja chegou voando. Seu ninho estava localizado entre as vigas em um dos grandes sótãos, e ela costumava voar para lá através de uma pequena abertura na calha do telhado.

Mas antes que ela pudesse encontrar a abertura, o vento a pegou, arrepiou suas penas de modo a fazê-la parecer uma grande bola e jogou-a algumas vezes contra a pa- 
rede. Então a coruja desistiu de todas as tentativas de entrar. Em vez disso, sentou-se na macieira e gritou durante toda a noite.

O interior da construção estava muito calmo e silencioso, mas pela luz que filtrava pelas fendas dos caixilhos podia-se ver que as pessoas não tinham ido para a cama. Uma ou duas vezes ouviu-se o som do riso. Logo depois, tudo se tornou mortalmente silencioso outra vez.

Às onze horas chegou a velha governanta da fazenda, que estava completamente vestida e carregava as chaves no cinto, como se não pudesse afastar-se delas durante o dia ou a noite, e entrou no vestíbulo.

A pesada porta era trancada com quatro fechaduras diferentes, e passou-se muito tempo até que a velha conseguisse abri-la. Assim que conseguiu, o vento aproveitou o momento, escancarou a porta, enviou uma enorme dose de chuva na cara da governanta e girou ao redor dos carpetes no vestíbulo, para que se contorcessem como cobras. A velha fechou a porta e saiu noite afora. Caminhou muito rápido como se estivesse assombrada por um grande terror, e constantemente murmurava:

- Deus nos proteja! Deus nos proteja!

Ela iluminou seu caminho com uma lanterna, mas estava tão preocupada em pensar sobre o que a assustava e preocupava que não fez uso da luz, e em vez disso pisou em poças d'água que podia muito bem ter evitado. Uma e outra vez, sua confusão fez com que ela se afastasse do caminho, caminhasse na grama e se enredasse em um arbusto de espinhos que rasgava um pequeno pedaço de seu vestido. Nada disso ela parecia notar. Continuou andando sem parar, enquanto murmurava:

- Deus nos proteja! Deus nos proteja!

Por fim ela chegou aos estábulos. Subiu a pequena e estreita escada que levava ao celeiro e parou no alçapão de entrada. A luz podia ser vista de dentro da abertura, e quando a governanta se inclinou para a frente ela pôde ver o interior de uma pequena sala, onde as paredes estavam cheias de arreios, rédeas, selas e correias. Na verdade, não era um quarto, mas apenas uma seção fechada do celeiro.

O feno entrava por entre as rústicas paredes de madeira, e no meio do cômodo havia um alçapão pelo qual se podia descer até os estábulos. Numa cama no canto da câmara estava sentado o velho cocheiro da fazenda. Ele valia-se da luz de uma lasca de madeira em chamas para ler as palavras de Deus. Estava sentado lá, como se não tivesse encontrado suficiente tranquilidade para dormir no meio da tempestade. Erguia constantemente o olhar do livro e escutava a tempestade, a chuva e os gritos de corujas.

A governanta bateu na abertura e o cocheiro foi abri-la. Imediatamente ele começou a desculpar-se por manter uma chama viva no celeiro. Ele parecia imaginar que a governanta tinha saído à noite com o único propósito de lhe pedir para ter cuidado com o fogo.

- Eu sei muito bem que é perigoso - disse ele -, mas pensei que era necessário que alguém lesse as palavras de Deus esta noite. 
A velha não respondeu. Sentou-se em cima de uma velha caixa cheia de pedaços de couro e ferro.

Ainda estava dominada por um terror tão profundo que parecia ter perdido o juízo; suas mãos puxavam o avental e seus lábios moviam-se com um murmúrio constante e ininteligível.

O cocheiro sentou-se e olhou para ela, até que o terror que a assombrava passou também para ele. Suas velhas mãos cansadas e suas mandíbulas desdentadas tremiam.

- Você já teve um encontro com Gamlefar [Pai Velho]? - o cocheiro perguntou em um sussurro.

Gamlefar era o duende. Ele nunca fora conhecido por outro nome naquela fazenda.

- Não - disse a governanta -, e eu nunca deveria ter medo dele. Ele só quer o nosso bem.

- Você não deveria ter tanta certeza disso - disse o cocheiro. - Ele é realmente um patrão muito rigoroso, e ultimamente têm acontecido na fazenda muitas coisas que lhe desagradam.

- Se ele fosse tão rigoroso como você pensa, não permitiria que o cavaleiro se comportasse como faz.

O cocheiro tentou acalmá-la.

- Lembre-se de que está falando sobre o nosso patrão.

- Isso não me impede de ver que está destruindo a si mesmo e à fazenda - queixou-se ela.

- O cavaleiro é o patrão da fazenda. Nós somos apenas seus pobres servos - disse o cocheiro com uma voz importante. Mas de repente, sua voz mudou e ele perguntou com profunda ansiedade:

- Ele está fazendo novas loucuras?

- Eu fiquei na porta do salão durante toda a noite e ouvi-o perder todo o dinheiro no jogo - disse a velha enquanto sacudia o corpo de um lado para outro. - Quando ele ficou sem dinheiro, começou a perder os cavalos e as vacas. Quando não havia mais animais, começou a apostar a fazenda. Ele está oferecendo herdade atrás de herdade, floresta atrás de floresta, pastagem atrás de pastagem, campo atrás de campo, e está perdendo tudo.

O cocheiro quase se levantou quando ouviu tudo isto, como se quisesse apressar-se para evitar toda essa calamidade. Mas então sentou-se novamente, com uma sensação de impotência.

- O cavaleiro é o patrão desta fazenda - disse. - Ele pode fazer o que quiser com o que lhe pertence. Mas eu não consigo entender por que Gamlefar não se envolve no jogo.

- Ele está sempre aqui no estábulo e provavelmente não sabe o que acontece na mansão - disse ela.

Durante muito tempo o celeiro ficou silencioso. Por fim, o cocheiro perguntou:

- Quem está jogando com o cavaleiro esta noite? 
- É o capitão Duwe, aquele que sempre ganha assim que toca nos dados.

- Esse homem é tão desprovido de posses quanto de bondade no coração - disse o cocheiro pensativamente. - $\mathrm{O}$ cavaleiro não pode esperar nenhuma misericórdia.

- Nesse exato momento é ele o proprietário de toda Töreby.

O cocheiro pegou a Bíblia, virou-se de lado para fazer bom uso da luz e começou a ler.

- Eu pensei que ia perder a cabeça, quando estava lá, ouvindo-os - disse a governanta. - Foi terrível. No início eles estavam de bom humor, e nosso patrão ria de tudo o que perdia jogando. Mas agora eles estão calados, exceto quando o cavaleiro perde novas terras. Então ele pragueja, e o outro ri.

O velho cocheiro murmurou e leu, mas não pronunciou palavras bíblicas. Nenhumas palavras vieram de seus lábios exceto estas:

- Herdade atrás de herdades, floresta atrás de floresta, pastagem atrás de pastagem, campo atrás de campo.

- De que sua leitura ajuda? - perguntou a governanta. - Se você fosse um homem de verdade, entraria lá e imediatamente o faria parar antes que perca toda a fazenda.

- Servi tempo suficiente neste lugar para saber exatamente o quão fácil é fazer um Silfverbrandt parar de fazer o que começou. Seria o mesmo que tentar trazer os mortos de volta à vida.

- Bem, isso talvez fosse o bastante, trazer de volta os pais dele - disse a governanta.

O cocheiro fechou o livro.

- Essa é a pior parte de tudo isso: ele não entende que não não pode levar uma vida dessas aqui nessa fazenda. Me lembro de todas as vezes que eu disse ao seu falecido pai: "Não dê Töreby ao senhor Henrik, ele nunca poderá se tornar um patrão que Gamlefar aprovararia. Dê-a ao seu irmão, que é de mente sadia e disposição séria, e dê ao senhor Henrik uma outra fazenda que não exija tanta responsabilidade!”.

- E agora Töreby não pertence nem ao senhor Henrik, nem ao senhor August. Ela pertencerá a esse capitão Duwe até que ele a perca para outra pessoa.

O cocheiro levantou-se decidido. Abotoou a camisa e removeu a lasca de madeira da forquilha. Estava claro que sua intenção era tentar conversar com o patrão. Mas quando ele levantou a lasca, segurou-a de forma que a luz caiu sobre a abertura quadrada no chão, através da qual pretendia descer para o estábulo. E tanto o cocheiro quanto a governanta viram que um duende estava na escada que se projetava através da abertura quadrada. Ele estava no topo da escada, era minúsculo e cinzento e vestia calções e uma jaqueta cinza com botões de prata. Ele escutava com tanto temor e tanta indignação que parecia ter se transformado em pedra.

O cocheiro e a governanta imediatamente desviaram o olhar. Nenhum deles mostrou qualquer sinal de ter visto o duende.

- Bem, acho que seria melhor que nós que somos velhos fôssemos para a cama agora - disse o cocheiro num tom de voz que ele tentou fazer soar despreocupado. - Você 
sabe que nesta fazenda não há necessidade de ficar acordado toda a noite, mesmo que acontecimentos infelizes já fossem de esperar. Há alguém que vigia por aqui.

- Sim, você tem razão. Há alguém vigiando aqui - disse ela, desanimada. Sem dizer mais uma palavra, pegou a lanterna, rastejou pela abertura e saiu pelas escadas do celeiro.

Quando a velha entrou na casa, decidiu ir para a cama de imediato, porque sabia que as vigílias desnecessárias à noite seriam as coisas que o duende provavelmente menos perdoaria. Ela também acreditava que ele endireitaria as coisas novamente, agora que tinha ouvido o que estava acontecendo. Porém mal conseguira soltar qualquer coisa além das pesadas chaves quando foi tomada por um desejo tão intenso de conhecer a situação entre os dois jogadores que mais uma vez caminhou silenciosamente rumo à porta para o salão.

Quando se inclinou e espiou pelo buraco da fechadura, viu que o cavaleiro Silfverbrandt e o capitão Duwe ainda estavam sentados na mesa de jogo. O cavaleiro parecia terrivelmente cansado e exausto. A governanta achou que ele havia mudado completamente durante o tempo em que ela estivera ausente. Ele não era nem bonito, nem jovem, nem majestoso, mas pálido e arruinado, com bolsas sob os olhos, sulcos na testa e mãos desajeitadas. O rosto de Duwe estava vermelho e seus olhos estavam raiados de sangue, mas ele ocultava a exasperação com conversas amigáveis e risos constantes.

A governanta não tinha passado mais de dois minutos escutando atrás da porta quando Silfverbrandt empurrou a cadeira para trás e exclamou:

- Está terminado, Duwe. Não tenho mais nada da fazenda para além da ilhota de pinheiros no lago. Você deve me deixar mantê-la para que ainda haja algo nesta terra que eu possa chamar de meu.

Duwe riu, mas não parecia satisfeito.

- É uma vergonha terminar o jogo dessa maneira - disse. - Agora que você já se atreveu a apostar tudo mais, não há por que não arriscar aquele monte de pedras também.

Silfverbrandt pôr-se a andar de um lado para o outro na sala. Estava claro que ainda se encontrava possuído pela luxúria do jogo. Lamentou menos o fato de ter perdido tudo do que o fato de não poder mais jogar.

- O que você vai apostar contra essa ilhota? - ele perguntou.

Duwe pensou por um momento. A governanta entendeu que estava tentando pensar em algo que certamente faria Silfverbrandt continuar.

- Vou apostar seu cavalo, disse Duwe.

Silfverbrandt amava seu cavalo mais do que qualquer outra coisa no mundo. Ele começou a praguejar horrivelmente. Perguntou se Duwe era o próprio Diabo, para tentá-lo daquela maneira.

A governanta percebeu que toda vez que o cavaleiro chegava a uma parte escura da sala, onde Duwe não o via, ele apertava os punhos de raiva.

- A pior parte é que eu sei que vou matar você quando o vir montando meu cavalo e comandando a minha fazenda - ele disse a Duwe. 
- Você não pode deixar que um homem pobre esteja um pouco despreocupado em seus dias de velhice? - perguntou Duwe, rindo. - Você é jovem e forte, logo encontrará um novo cavalo e uma nova fazenda num outro lugar.

Durante todo o tempo em que estava ali, a governanta se perguntava o que estava acontecendo com a porta que saía do salão para o vestíbulo. Vez após vez, foi entreaberta e então novamente fechada. Mas a cada vez que Silfverbrandt passava por aquela porta, parecia que uma pequena mão se estendia pela abertura e acenava para ele. Silfverbrandt passou em frente à porta várias vezes sem notar nada, mas de repente parou e olhou para ela.

- Então, você vem? - perguntou Duwe.

- Volto em um instante - disse Silfverbrandt, saindo para o vestíbulo.

Silenciosa como uma sombra, a governanta deslizou para longe da porta. Um segundo depois, estava na despensa, olhando através de uma pequena janela que dava para o vestíbulo.

Silfverbrandt estava ali, inclinado sobre o duende. Gamlefar segurava uma pequena lanterna, que espalhava luz no quarto escuro.

- O que você vai me dar, se eu cuidar para que você recupere a fazenda? - perguntou o duende.

- Vou dar-lhe o que quiser - disse Silfverbrandt.

O duende enfiou a mão dentro do bolso e tirou um conjunto de dados.

- Se eu emprestar esses dados e você usá-los para jogar esta noite, acho que você vai ganhar a fazenda de volta - disse o duende a Silfverbrandt.

Silfverbrandt estendeu as mãos.

- Dê-me! Dê-me! - disse ele.

- Você só vai tê-los com uma condição, que é jogar amanhã comigo fazendo a aposta que eu decidir - disse o duende.

Naquele momento, a pobre coruja soltou um grito alto e terrível. Silfverbrandt olhou para cima e escutou. A velha governanta viu que os olhos do duende haviam começado a reluzir de malícia e ódio.

Ela queria quebrar a janela e gritar ao patrão que não fizesse qualquer acordo com ele. Mas naquele momento, o duende a olhou com um olhar terrível. Ela permaneceu imóvel sem ousar mover um único dedo.

Mas Silfverbrandt também parecia ter visto algo horrível no duende. Ele puxou a mão para trás e quase voltou para o salão.

E então parou.

- Eu não sei por que devo acreditar em qualquer coisa ruim sobre você, Gamlefar. Você sempre se importou muito com esta fazenda - disse ele. - Tenho certeza que você só deseja o meu bem. Dê-me os dados, então! Amanhã o que deve acontecer vai acontecer, contanto que eu possa deixar Duwe tão pobre hoje à noite como era quando entrou por este vestíbulo anteontem. 
No momento seguinte Silfverbrandt já estava no salão.

- Não vou ficar aqui ouvindo corujas gritando e tempestades soprando sem jogar - disse Duwe. Vou para a cama agora.

- Você não quer ganhar aquela ilhota primeiro? - perguntou Silfverbrandt, enquanto se sentava à mesa.

Ele pegou o pequeno copo onde estavam os dados e os sacudiu. Depois disso, ele e Duwe jogaram por horas, mas Silfverbrandt ganhou todas as rodadas.

Durante esse tempo, a tempestade cessou, a coruja conseguiu voltar para dentro do ninho e a velha governanta teve que ir para a cama por causa da exaustão, mas Silfverbrandt não descansou até ganhar de volta herdade atrás de herdade, floresta atrás de floresta, pastagem atrás de pastagem, campo atrás de campo, de modo que toda Töreby voltou a ser sua.

Fez uma bela manhã depois daquela noite tempestuosa: um céu alto e azul, ar puro e um lago claro como um espelho.

A velha governanta foi chamada para o dormitório do cavalheiro enquanto ele ainda estava na cama.

Quando ela abriu a porta, pensou que algo pequeno e cinzento parecia ter passado depressa por ela.

Ela só viu o suficiente para sobressaltar-se. E então aquilo desapareceu.

O cavaleiro Silfverbrandt estava deitado na cama, muito pálido.

- Você o viu? - perguntou ele.

- Não - respondeu ela, por hábito. Acreditava-se que o duende não ficava satisfeito quando as pessoas falavam de tê-lo visto.

- Foi Gamlefar - disse o cavaleiro. - Ele saiu assim que você chegou. Ele jogou dados comigo.

A governanta olhou fixamente para o cavaleiro.

- Gamlefar não está muito satisfeito comigo - disse o cavaleiro. - Preferia que meu irmão tivesse a fazenda. E talvez você também preferisse.

O cavaleiro parecia incrivelmente estranho. A velha não sabia o que responder.

- Pelo menos, eu consegui tirar o velho Duwe da fazenda - Silfverbrandt continuou. - Eu tinha planejado agradecer Gamlefar deixando que as coisas aqui na fazenda fossem feitas à maneira dele, mas ele não tem fé em mim. Ele faz as mais estranhas apostas no jogo, esse duende. É pior do que Duwe.

A governanta começou tremendo e murmurando como havia feito durante a noite.

- Deus nos proteja!

- Ora, não fique aí parecendo chateada - disse Silfverbrandt. - Apresse-se e arrume o meu uniforme! Trate de polir a bandoleira, esfregar os botões e remover as manchas! Meu cavalo de equitação deve também ser selado com o melhor equipamento! A crina do cavalo deve ser penteada, os estribos e as tiras de couro devem ficar a brilhar! 
A governanta olhou surpreendida para o patrão. Ela saiu e imediatamente voltou com o uniforme. Numa fazenda como Töreby, não havia nada que não estivesse polido e escovado, brilhante e bem cuidado.

Assim, o cavalheiro Silfverbrandt levantou-se da cama, vestiu o uniforme azul, colocou o chapéu de três pontas na cabeça, amarrou o sabre ao lado e pôs as luvas longas e rígidas nas mãos. Ele saiu para a varanda e montou seu cavalo, que estava esperando por ele lá fora.

Por duas vezes deu uma volta de cavalo pela fazenda, e depois voltou-se para o lago e o trapiche de lavagem, que ia da margem para o interior lago, e que existia naqueles dias assim como hoje. Ele parecia tão majestoso e grandioso quando estava montando que todos os criados foram admirá-lo. Tanto o cocheiro como a governanta podiam ver que o duende estava debruçado no estábulo, olhando para o dono da fazenda.

Quando o cavaleiro chegou à margem do lago, cavalgou pelo trapiche. Sentou-se na sela empertigado e orgulhoso como um herói, e o cavalo se moveu com passos curtos e dançantes. Quando haviam cavalgado até o fim do trapiche, uma pequena luta eclodiu entre o cavalo e seu mestre. O cavalo queria voltar atrás, mas o cavaleiro Silfverbrandt o forçou a avançar com o chicote de equitação e as esporas. E então, com um grande salto, o cavalo lançou-se na água.

Todas as pessoas que estavam na fazenda correram para o lago. Mas quando chegaram, o cavalo e seu mestre tinham desaparecido. Tinham ido para o fundo do lago sem reaparecer.

Os rapazes entraram nos barcos e remaram lago adentro. Todos falaram e tentaram oferecer ajuda e conselho, mas a velha governanta permaneceu imóvel.

- Não vale a pena - disse. - É o duende. O dono jogou sua vida nas mãos do duende por causa da ajuda que recebeu ontem à noite.

Quando o povo, perturbado e horrorizado, regressou à fazenda, o duende de Töreby estava em frente ao alçapão do estábulo, acenando triunfantemente o gorro vermelho.

Sabia que mais uma vez haveria ordem, quietude e prudência em Töreby. 


\section{Mötet med den Grå Mannen}

\section{Max Lundgren}

Min farmor var en lång bister kvinna, med ett stort svartgrått hår, oftast bundet i en knut på nacken. Min farfar var rundare, och syntes därför kortare. Han hade sin keps på sig när han sov. Kanske var han skallig. Jag såg honom aldrig utan sin keps.

De var så olika som två människor kan vara. De talade sällan med varandra. Trots sin bistra uppsyn hade min farmor ett svärmiskt drag. Varje kväll gick hon ut vid tiotiden och hade ett samtal med Den Grå Mannen. Ofta talade hon mycket länge med honom. De tycktes trivas bra ihop, hon och Den Grå Mannen.

Min farfar tyckte inte om Den Grå Mannen, och Den Grå Mannen tyckte inte om min farfar. En gång försökte min farfar skjuta Den Grå Mannen med ett hagelgevär.

- Nils, sa min farmor, han är ju redan död.

- Ett skott i ändan behöver han, döing eller inte, svarade min farfar när han hängde upp geväret innanför dörren.

De bodde alla tre en bit upp på Hallandsåsen, långt ifrån all bebyggelse. Skogen växte ända in på stugan, och på vintrarna snöade de inne och fick klara sig bäst de kunde. Den Grå Mannen snöade inte inne. Han gick ljudlöst och utan skugga och fotsteg över den meterhöga snön. Min farmor öppnade fönstret på kvällarna och talade med honom.

- Kärringen vill min död, muttrade min farfar. Undrar om man kunde gillra en jättelik råttfälla och bli av med honom för gott?

Den Grå Mannen störde min farfar. Det var nämligen så att min farfar hade nått den ålder då allt var färdigt. Han hade satt saker och ting på dess rätta plats. Bönder var opålitliga och snåla. Stadsbor var giriga och förstod sig inte på natur. Middag skulle man sova klockan två på dagen. Människor i allmänhet var inte riktigt kloka. Ett hagelgevär var alltid bra att ha. Och så vidare. Men Den Grå Mannen passade inte in i bilden. Han störde min farfars orubbliga värld.

- En gång ska han åka dit, mumlade han ofta för sig själv.

Jag själv hade nått samma stadium som min farfar. Jag var sexton år och visste allt. Några spöken fanns inte. Grå män var inbillning och ingenting annat.

Det här året reste jag upp till dem i mars. Det mesta av snön var borta. Till och med här uppe i skogstrakterna anade man våren i luften.

Jag kom in i stugan. Allt var sig likt. Värmen. Doften från vedspisen. Min farmor, lika orubbligt rak i ryggen, håret bakåtkammat. Min farfar. Den eviga kepsen. Han satt vid radion och nickade förstrött åt mig. 
- Du är hungrig som vanligt, sa min farmor, och gick ut i köket och började laga mat. Jag satte mig hos farfar.

- Hur är det?

- Hmmm.

Hans sätt att tala var mycket korthugget.

- Hur har vintern varit?

- Hmmm. En sån till. Slut med mig.

- Kallt?

- Nej, tusan. Den Grå Mannen.

- Vad är det med honom nu då?

- Drag. Ont i nacken. Kärringen har stått i fönstret hela vintern. Jag tåler inte drag. Han vet det.

- Vem då?

- Han som inte finns.

Det lät egendomligt.

- Måste bli av med honom, sa min farfar. Hör på. Jag har en plan. Vi kan tala i vedbon senare.

Min farmor kom in med mat. Vi åt under tystnad. Det hörde till. Efteråt berättade jag om skolan, om släktingar och om allt annat som jag trodde kunde intressera de gamla. De nickade då och då. Men det var som om dom levde för långt ifrån den vanliga världen. Det var som om dom inte riktigt förstod att det fanns tusentals människor på andra ställen som sprang hit och dit och hade dagarna fyllda av arbete och bestyr.

- Där ljög du, sa min farmor plötsligt. Den Grå Mannen sa att Kickan - min storasyster - inte alls bodde i Lund. Hon bor i Göteborg. Tillsammans med en karl!

- Hon studerar i Lund, farmor.

- Struntprat! Det vet väl Den Grå Mannen bättre.

Min farfar fnyste.

- Den Grå Mannen? Vad är det för dumheter, sa jag. Den Grå Mannen!

- Om jag var död, sa min farfar, skulle jag ha tusan så mycket viktigare saker för mig än att springa och hålla reda på vad Kickan gör. Lund eller Göteborg, ja vadå? Fånerier!

- Nils, sa min farmor, han tycker inte om när du talar så om honom. Han är en ren, vänlig, hygglig människa...själ, menar jag. Du får inte tala om äldre folk på det sättet.

- Hur gammal är han? frågade jag.

- Etthundraåttiosju.

- Ser han ut som det?

- Max! Du ska inte driva med mig eller Den Grå Mannen!

Prick klockan två la sig min farfar. Jag tror att det finns mycket få händelser som skulle ha fått honom att avstå från tvåsömnen. 
- Du ser blek ut, sa farmor till mig. Du sitter inne för mycket. Ut i skogen med dig. Här har du en säck. Plocka pinnar.

Jag tog säcken och gick. Himlen hade blivit grå och det småregnade. Jag gick i mina tankar. Jag tänkte på de två i stugan, eller på de tre om man så vill. Jag tänkte på hela denna djupa tysta vinter, som nu höll på att släppa greppet om trakten. Vad hade de talat om? Vad hade de gjort? Hur kunde människor leva så?

Regnet övergick i snö. Himlen blev blytung. Det mörknade utan att jag märkte det. Då och då stannade jag och tog upp en blöt pinne, bröt den i passande längd och la den i säcken. Snön föll allt tätare.

Plötsligt upptäckte jag att jag bara kunde se några meter framför mig. Jag stannade. Jag undrade var jag var. Jag gick snabbt tillbaka och följde mina spår. En kvart senare var de försvunna, dolda av snön.

Nu kände jag mörkret. Tallarna hade långa mörkblåa skuggor, som sakta rörde sina kronor på den vita snön. Enebuskarna var hemskare. De var mindre, och stod där som soldater framför mig, plötsligt, som om de stigit rätt ur marken. Jag började bli rädd.

Jag fortsatte på måfå ytterligare en halvtimme.

- Jag är förlorad, tänkte jag.

I detsamma hörde jag en röst:

- Hallå!

Det ordnar sig, tänkte jag.

- Hallå! ropade jag tillbaka.

Ur dunklet lösgjorde sig en man. Han var kraftigt byggd, med bred skulande rygg, en typisk höglandsbonde, som slitit mycket med sten och skog.

- Jag har gått vilse, sa jag.

- Jag ska visa dig, sa han och småskrattade. Det var ett gemytligt och stillsamt skratt.

- Inte kunde man tro att det skulle bli snö nu, sa han. Det är ju ändå mars.

- Här är ingenting som det ska, svarade jag.

- Ajo, snö i mars, det är inte vanligt det.

Vi fortsatte att småprata. Han gick före mig. Jag såg inte hans ansikte längre.

- Joo, sa han på sitt saktmodiga sätt, jag har ju levt hela mitt liv här, så jag vet.

- Jaså, sa jag. Ja, jag är från stan. Från Malmö.

- Mmm, det hörs. Och syns också för den delen.

Det blev allt mörkare.

- Gå inte så fort, sa jag. Då ser jag inte ryggen.

- Dom väntar dig, svarade han. Hon ska väl inte oroa sig för mycket?

En plötslig känsla av skräck fyllde mig.

- Vem? frågade jag. Han kluckade. 
- Jo, jo, sa han. Här har jag bott, och här tänker jag fortsätta att bo.

Han stannade, vände sig om och log åt mig. Hans ansikte var egendomligt grått. Han var grå i kläderna också. Ögonen var grå.

- Var? stammade jag.

- Här, sa han och knackade på dörren.

Då såg jag stugan. Mina farföräldrars stuga. Alltid snurrade runt. Mannen var plötsligt borta.

- Det är inte sant, tänkte jag. Det kan inte vara sant! Det finns inga grå män!

Dörren öppnades. Min farmor stod lång och bister på tröskeln.

- Han har ett gott hjärta, sa hon. Nu vet du det, Max. Det var Den Grå Mannen som hjälpte dig hem!

- Han är svår att tas med, sa farfar.

Det var dagen efter mitt möte med Den Grå Mannen och vi stod i vedbon.

- Men det måste bli han eller jag, fortsatte min farfar bestämt. Jag måste bevisa att han inte finns.

- För vem ska du bevisa?

- För honom själv, så klart! Se här. En katt. I buren. Tar alla småfåglar. Hade inte hjärta att slå ihjäl honom.

Katten stirrade på oss med sina gula ögon.

- Vi ska ordna ett eget spöke, sa farfar. Såja, lugn nu, kissemiss. Jag fäster de här små bjällrorna vid baktassarna, såja. Biss du, din...

Farfar arbetade metodiskt och lugnt. Han fäste ett snöre av bjällror vid kattens bakfötter. Han tillverkade en lucka som gick att öppna med ett snöre.

- Så hänger det ner i köket, sa han. Du smyger ut och drar. Katten promenerar ut på loftet och hon tror att det är ett nytt spöke. Hon berättar det för honom. Vad händer då?

- Jag vet inte, svarade jag osäkert.

- Inte jag heller, sa farfar och log. Men jag tror inte att han själv tror på spöken. Det du!

- Men vadå?

- Då har jag ju bevisat att han inte finns!

- Men jag förstår inte?

- Och då finns han inte! Finns inte! Finns inte! Borta!

Han gned sina händer av förtjusning.

- Du tar med henne ut i skogen. Jag monterar fällan. Klockan nio ikväll går du ut i köket för att dricka vatten. Snöret hänger i taket. Bara en liten tåt. Hon går inte och tittar i taket. Det gör ingen vettig människa. Sen ska vi se.

Klockan nio gick jag ut i köket och drog i tåten. Jag tog ett glas vatten och återvände in i rummet. Farfar satt med händerna knäppta och med nedböjt huvud, som om han tänkte 
på något viktigt. Farmor satt och sydde. Jag väntade tyst för mig själv. Så började bjällrorna höras. Först tyst, försiktigt - katten smög sig ur buren. Efterhand blev ljudet allt högre. Mina farföräldrar satt orörliga, som om de inget hörde. Efter en lång stund sa min farmor:

- Det är bjällror på loftet. Så vackert det låter.

Farfar svarade inte. Farmor fortsatte att sy. Då förändrades ljudet. Det blev dovare och dovare. Till slut lät det som kyrkklockor. Rädslan började krypa i kroppen på mig som en tusenfoting.

- Nu ringer klockorna på riktigt, sa farmor stillsamt. Farfar inte ens höjde på huvudet.

- Det låter hemskt, sa jag.

- Bara en stackars fattig själ som blivit instängd på loftet, sa farmor.

Återigen förändrades ljudet, och nu kändes det som om håret skulle resa sig på mitt huvud. Det stack och ilade i kroppen. Det var inte längre klockor. Det var tunga kedjor, som asade fram och tillbaka över golvet. Fram och tillbaka, mödosamt fram och tillbaka.

- Bäst jag släpper ut honom, sa farmor och reste sig upp.

När hon gick bort till vindstrappan såg farfar på mig. Vi reste oss båda och följde försiktigt efter.

Farmor gick uppför trapporna. Så öppnade hon dörren. Hon drog haspen från ytterdörren, och ställde den på vid gavel.

- Drag igen, muttrade farfar.

Det som hände sen höll på att skrämma livet ur mig. Jag hade väntat att få se katten komma som en blixt. Men det kom ingen katt. Ljudet kom i stället. Det rasslade nedför trapporna. Det sa, bom, bom, bom, som om det var stora kulor fästa vid kedjorna. Det gick långsamt.

Farmor stod orörlig och rak vid dörren. Farfar och jag stirrade med vidöppna ögon på den tomma trappan. Äntligen nådde det hemska ljudet ned på golvet. Det hördes ett hasande och ett flåsande, och så var det utanför dörren. Farmor stängde den stillsamt.

- Såja, sa hon lugnt, och gick tillbaka in i rummet för att fortsätta med det hon höll på med.

Utanför hörde farfar och jag ett tyst, kluckande skratt.

- Sablar också, han lurade oss! sa farfar.

- Katten, frågade jag.

Farfar steg upp för trappan till vinden. Jag följde efter. Jag kikade bakom hans axel. På golvet låg katten med benen i vädret. Bjällrorna hängde tysta längs bakbenen. Kattens ögon var brustna.

En kvart senare talade farfar med farmor.

- Hmmm, sa han. Jag vill språka med Den Grå Mannen.

- Inte säkert att han vill språka med dig. 
- Det tror jag nog.

- Vilken tid?

- När som helst.

- Jag ska fråga.

Hon svepte schalen om huvudet och gick ut.

- Gör det inte, farfar, sa jag.

- Det måste bli han eller jag.

- Slut fred med honom.

- Med en som inte finns? Som bara tror att han finns? Aldrig!

Farmor återvände.

- Ni har varit elaka mot Den Grå Mannen, sa hon. Men han har ett gott hjärta. Han talar gärna med dig i skogsdungen klockan tolv.

- Utmärkt, sa farfar.

Jag skallrade tänder, men ingen av dem tycktes märka det. Allt var som...vanligt.

Några minuter före tolv gav sig farfar iväg. Ingenting kunde ha hindrat honom, det såg jag i ansiktet på honom. Farmor och jag var ensamma kvar. Minut efter minut gick. Hon satt där lång och bister, men hennes ögon glimmade.

- Jaha, sa hon eftertänksamt. Nu făr vi se.

Jag satt och svalde. Jag drack mitt vatten. Jag önskade att jag var tusen mil från denna hemska plats. Tiden gick. Inte ett ljud hördes utifrån. Jag såg den döda katten framför mig. Jag rös till.

Klockan hade hunnit bli ett. Då hörde vi långsamma, stapplande steg. Någon lutade sig mot ytterdörren och andades tungt. Farmor reste sig utan att ändra en min. Hon öppnade dörren. Farfar stod där utanför. I lampskenet såg jag hur hans ansikte hade förändrats. Rynkorna hade djupnat. Skuggor låg mörka långt ner under ögonen. Pannan var våt av svett, som om han hade slagits.

- Kom in, sa farmor. Nå, vad sa Den Grå Mannen?

- Den Grå Mannen har sagt sitt för sista gången, väste farfar, och tog sig mödosamt in.

- Nils! Vad har du gjort?

- Ingenting.

- Som du ser ut!

- Det kostade!

Han tystnade och satte sig tungt.

- Han slog kepsen av mig, sa han sen.

Då stirrade farmor nästan skrämt på honom.

- Måste lägga mig, sa farfar. Den Grå Mannen finns inte mer. Jag är trött. Men jag lyckades. 
- Med vadå?

- Bevisa! Jag bevisade att han inte finns. Han finns inte mer!

Med de orden gick han till sängs. Efterhand la sig farmor och jag också. Jag låg länge vaken.

Nästa kväll gick farmor sin vanliga runda. När hon kom tillbaka såg hon för en gångs skull mycket ledsen ut.

- Han var inte där, sa hon. Nils! Vad har du gjort?

Farfar svarade inte.

Efter den kvällen sänkte sig tystnaden över huset. Jag stod ut tre dagar till. Sen åkte jag hem till Malmö.

En vecka senare ringde det på dörren. Min far öppnade.

- Nej, men kom in! sa han.

Det var farfar och farmor. Farfar talade.

- Det blev för ensamt där uppe. Kan vi få bo här tills vi får egen lägenhet?

- Det är klart!

- Det blev så tyst, sa farfar. Så konstigt tyst. Allting i huset blev tyst. Jag skulle aldrig ha sagt att han inte fanns.

- Vem då? frågade min far förvånat.

Jag visste svaret.

Farfar suckade.

- Jag saknar honom faktiskt. Den Grå Mannen.

Så hörde jag min farmors röst. Jag blev förvånad. Hon tröstade farfar!

- Var inte ledsen, Nils. Det finns fler. Det finns säkert många. Här också.

Jag rös till.

- Men ingen som vår, sa farfar jämrande. Han hade nog ett gott hjärta i alla fall. Hade han bara inte slagit kepsen av mig! 


\section{Encontro com o Homem Cinzento}

\section{Max Lundgren}

Tradução do sueco:

Tobias da Rocha

Minha avó era uma mulher alta e severa, e seu cabelo grande era preto e grisalho e frequentemente amarrado em um nó no pescoço. O meu avô era corpulento, e assim parecia mais baixo. Ele usava o boné quando dormia. Talvez ele fosse careca. Eu nunca o vi sem o boné.

Os dois eram tão diferentes quanto humanamente possível, e raramente falavam um com o outro. Mas, apesar da aparência séria, a minha avó tinha uma veia romântica. Todas as noites, ela saía às dez e tinha uma conversa com o homem cinzento. Muitas vezes eles falavam por muito tempo. Parecia que se davam muito bem.

Meu avô não gostava do homem cinzento, e ele não gostava do meu avô. Uma vez meu avô tentou atirar no homem cinzento com uma espingarda.

- Nils! Ele já está morto - disse minha avó.

- Ele precisa de um tiro no traseiro, morto ou não - disse meu avô enquanto pendurava a espingarda.

Os três viviam no cume de Halland, longe de toda a civilização. A floresta crescia perto da casa, e no inverno a porta ficava bloqueada pela neve, e eles tinham que suportar aquilo da melhor forma possível. O homem cinzento não estava incomodado com a neve. Ele caminhou sobre ela sem fazer barulho, sem sombra e sem pegadas. À noite, minha avó abria a janela e falava com ele.

- A velha bruxa me queira morto - disse meu avô. - Talvez eu pudesse fazer uma grande ratoeira e livrar-me dele para sempre?

O homem cinzento perturbava o meu avô, porque meu avô tinha atingido uma idade em que tudo estava acabado. Ele tinha colocado tudo no devido lugar. Os camponeses eram sovinas e desonestos. Os habitantes das cidades eram gananciosos e não entendiam a natureza. Deve-se sempre tirar uma soneca às duas horas. As pessoas, em geral, eram loucas. Era sempre útil ter uma espingarda. E assim por diante. Mas o homem cinzento não se encaixava. Ele perturbava a visão de mundo inflexível do meu avô.

- Mais cedo ou mais tarde, ele vai ser tratado - dizia meu avô.

Eu tinha chegado à mesma conclusão do meu avô. Eu tinha dezesseis anos e sabia de tudo. Fantasmas não existem. Homens cinzentos eram imaginação e nada mais.

Este ano eu fui visitá-los em março. A maior parte da neve tinha desaparecido, e mesmo no meio da floresta podia-se notar que a primavera estava chegando. 
Eu entrei na casa. Tudo parecia normal. O calor. O cheiro do fogão a lenha. A minha avó, as costas empertigadas como sempre, e seu cabelo penteado para trás. Meu avô com o boné, como sempre. Ele estava sentado ao lado do rádio e acenou para mim.

- Você está com fome, como sempre - disse minha avó, entrou na cozinha e começou a cozinhar.

Eu me sentei ao lado do meu avô.

- Tudo bem?

$-\mathrm{Hmmm}$.

Sua maneira de falar era muito espartana.

- Como foi o inverno?

- Hmmm. Mais um inverno como este. Vai ser o meu fim.

- Foi frio?

- Não. O homem cinzento.

- Que lhe aconteceu?

- Correntes de ar frio. Tenho dor de pescoço. Ela ficou permanentemente na janela durante todo o inverno. Não aguento as correntes. Ele sabe disso.

- Quem?

- Aquilo que não existe.

Soou estranho.

- Tenho que me livrar dele - disse meu avô. Tenho um plano. Podemos falar mais tarde no telheiro.

Minha avó trouxe a comida. Nós comemos em silêncio, como de costume. Depois, eu falei-lhes sobre a escola, sobre parentes e sobre tudo o que eu imaginei que eles pudessem achar interessante. Às vezes eles assentiam. Mas parecia que viviam longe demais do mundo normal. Parecia que não entendiam que havia inúmeras pessoas em outros lugares, cujos dias eram cheios de trabalho e tarefas.

- Isso foi uma mentira, disse minha avó de repente. - $\mathrm{O}$ homem cinzento disse que Kickan (minha irmã) não vive em Lund. Ela vive em Gotemburgo. Com um homem!

- Ela estuda em Lund, avó.

- Absurdo! O homem cinzento saberia disso.

O meu avô zombou. Eu perguntei:

- O homem cinzento? Que tolice é essa?

- Se eu estivesse morto, haveria muito mais coisas importantes para me preocupar do que saber onde Kickan vive - disse meu avô. - Lund ou Gotemburgo? Qual é a diferença? Disparate!

- Nils - disse minha avó -, ele não gosta quando falam sobre ele desse jeito. Ele é uma pessoa boa e decente... quero dizer, uma alma boa e decente. Você não deve falar assim dos idosos. 
Eu perguntei:

- Que idade ele tem?

- Cento e oitenta e sete.

- Parece tão velho?

- Max! Você não deve tirar sarro de mim ou do homem cinzento!

Às duas da tarde o meu avô foi dormir. Acredito que havia muito poucas coisas que poderiam impedi-lo de tirar uma soneca.

- Você está pálido - disse minha avó. - Você passa tempo demais dentro de casa. Vá para a floresta. Tome este saco. Pegue uns gravetos.

Eu tomei o saco e saí. O céu havia se tornado cinzento e estava chovendo um pouco. Eu andei e ponderei. Pensei sobre aqueles dois - ou talvez três - na casa. Pensei sobre o inverno profundo e silencioso, que estava desaparecendo lentamente da área. $\mathrm{O}$ que foi que eles tinham falado? O que tinham feito? Como as pessoas podem viver assim?

A chuva transformou-se em neve. A escuridão veio sem que eu notasse. De vez em quando eu parava de andar e pegava um graveto, para então quebrá-lo num comprimento adequado e colocá-lo no saco. A neve continuava a cair.

De repente, percebi que eu só enxergava uns poucos metros à frente. Parei e me perguntei onde eu estava. Rapidamente eu voltei pelo caminho das minhas pegadas. Depois de quinze minutos elas tinham desaparecido na neve.

Eu podia sentir a escuridão se aproximando. Os pinheiros tinham sombras em azul-escuro que se moviam lentamente pela neve branca. Os arbustos de zimbro eram ainda mais terríveis. Eram mais curtos, e estavam ali como soldados na minha frente, como se tivessem surgido da terra. Comecei a sentir medo.

Continuei andando ao acaso por uma meia hora.

"Estou perdido", pensei. Naquele momento, ouvi uma voz.

- Olá!

Tudo vai ficar bem, pensei, e respondi: “Olá!”.

Um homem surgiu da escuridão. Ele tinha uma grande estatura e ombros curvados; um camponês típico das montanhas, que tinha trabalhado muito com as pedras e a floresta.

- Eu perdi o meu caminho - disse eu.

- Vou mostrar-lhe - disse ele, rindo. Era um riso simpático e tranquilo.

- Quem acreditaria que haveria queda de neve agora? Disse ele. Afinal de contas, é março.

- Nada é normal aqui - eu respondi.

- Ah não, neve em março, isso é incomum.

Continuamos conversando. Ele caminhava na minha frente. Eu já não podia ver seu rosto.

- Sim - disse ele lentamente -, eu vivi aqui toda a minha vida, e portanto sei isso por experiência. 
- Legal - eu respondi. - Eu sou da cidade. De Malmö.

- Mmm, estou ouvindo. E vendo também.

Foi ficando mais escuro.

- Não ande tão depressa - eu disse. - Não consigo vê-lo.

- Estão esperando por você - ele respondeu. - Você não quer que ela se preocupe muito, não é?

De repente tive uma sensação de medo.

- Quem? - perguntei. Ele riu.

- Certamente - disse ele -, eu vivi aqui e vou continuar vivendo aqui.

Ele parou de andar e se virou para mim, sorrindo. Seu rosto era estranhamente cinzento. Suas roupas eram cinzentas também. Seus olhos eram cinzentos.

- Onde? - gaguejei.

- Aqui - ele respondeu, batendo na porta.

De repente, eu vi a casa. A casa dos meus avós. Eu vi tudo andando à minha roda. O homem tinha desaparecido.

"Não foi real”, pensei. Não poderia ter sido real! Não há homens cinzentos!

A porta se abriu. Minha avó estava ali, alta e severa.

- Ele tem um bom coração, Max - ela disse. - Você já sabe disso. Foi o homem cinzento que lhe ajudou a voltar para casa!

- É difícil lidar com ele - disse meu avô.

Foi no dia depois do meu encontro com o homem cinzento. Estávamos no telheiro.

- Mas tem que ser ele ou eu - disse meu avô com firmeza. - Tenho que provar que ele não existe!

- Provar para quem?

- Para ele, claro! Veja só. Um gato. Naquela gaiola. Ele pega todos os passarinhos. Não tive coragem de matá-lo.

O gato olhou para nós com seus olhos amarelos.

- Vamos criar nosso próprio fantasma - disse meu avô. - Calma, gatinho. Vou amarrar esses guizos às suas patas traseiras. É isso aí. Você me mordeu, seu...!

Meu avô trabalhou calma e metodicamente. Amarrou um barbante com guizos às patas traseiras do gato. Depois, ele preparou uma tampa para a gaiola, que podia ser aberta por meio de uma corda.

- A corda vai ser pendurada no teto da cozinha. Você vai entrar e puxá-la. O gato vai correr para o sótão, e ela vai acreditar que é um novo fantasma. Ela vai contar-lhe isso. E então, o que vai acontecer?

- Não sei - respondi eu, inseguro.

- Eu também não - disse ele, sorrindo. - Mas eu não acho que ele acredita em fantasmas! 
- Mas e então?

- E então vou provar que ele não existe!

- Mas...não entendo?

- E então ele não vai existir! Não vai existir! Não vai existir! Vai ter desaparecido!

Ele esfregou as mãos de prazer.

- Você precisa levar sua avó para a floresta. Vou preparar a armadilha.

Às nove da noite, você vai para a cozinha beber água. A corda vai estar pendurada no teto. É só um pedacinho de corda. Ela não vai olhar para o teto. Ninguem no seu juízo perfeito faz isso. Depois veremos o que acontece.

Às nove da noite eu fui para o cozinha e puxei a corda. Tomei um copo de água e voltei para a sala de estar. Meu avô estava sentado com os dedos entrelaçados e a cabeça inclinada para baixo, como se estivesse pensando em coisas importantes. Minha avó costurava. Esperei em silêncio. De repente os guizos começaram a soar. No início, o som veio silenciosamente e com cautela - o gato saiu da gaiola. Mas logo o som tornou-se mais alto. Meus avós estavam imóveis, como se não ouvissem nada. Depois de um longo tempo, minha avó disse:

- Há sinos no sótão. Soam bem.

Meu avô não respondeu. Minha avó continuou costurando. Então o som mudou. Ficou mais pesado. Finalmente, soou como sinos de igreja. O medo começou a rastejar pelo meu corpo como uma centopeia.

- Os sinos estão tocando de verdade agora - disse minha avó calmamente.

- Soa horrível - disse eu.

- É apenas uma pobre alma que ficou presa no sótão - disse minha avó.

Mais uma vez o som mudou, e eu sentia como se meu cabelo estivesse em pé. Tive sensações de frio e calor por todo o meu corpo. O som não era mais de sinos. Era de correntes pesadas, arrastadas lentamente pelo chão, para a frente e para trás, com grande esforço, para a frente e para trás.

- Melhor tratar de soltá-lo - disse minha avó, se levantando.

Quando ela andou em direção às escadas para o sótão, meu avô olhou para mim. Pusemo-nos de pé e a seguimos cuidadosamente.

Minha avó subiu as escadas. Ela abriu a porta e voltou para baixo. Depois, soltou o trinco e abriu por inteiro a porta da frente.

- Ar frio outra vez - murmurou meu avô.

O que aconteceu depois quase me matou de susto. Eu estava esperando para ver o gato vir correndo rápido como um raio. Mas o gato não veio. Em vez disso, o som veio. Lentamente, chocalhou pelas escadas. Houve sons estridentes, como se houvesse grandes esferas de metal presas a correntes. Aquilo se movia devagar.

Minha avó ficou completamente imóvel, com as costas empertigadas. Meu avô e eu olhávamos com os olhos arregalados para as escadas vazias. Por fim aquele som terrível 
chegou ao nível do chão. Ouviu-se um arrastar de pés e um suspiro, e depois o som estava do outro lado da porta.

Minha avó a fechou lentamente.

- Tá bom - ela disse calmamente, e então voltou para dentro para continuar o que estava fazendo.

Do lado de fora, meu avô e eu ouvimos uma risada silenciosa.

- Droga, ele nos enganou! - disse meu avô.

Eu perguntei:

- O gato?

Meu avô subiu as escadas para o sótão. Eu o segui e olhei por cima de seus ombros. No chão, o gato estava deitado com as pernas erguidas. Os sinos pendiam silenciosamente das patas traseiras. Os olhos do gato estavam furados.

Quinze minutos depois, meu avô falou com minha avó.

- Quero falar com o homem cinzento - disse meu avô.

- Não tenho certeza se ele quer falar com você.

- Acho que quer.

- Quando?

- A qualquer momento.

- Vou perguntar para ele.

Ela enrolou o xale em volta da cabeça e saiu.

- Não faça isto, avô - eu disse.

- Tem que ser ele ou eu.

- Faça as pazes com ele.

- Com alguém que não existe? Que só pensa que existe? Nunca!

Minha avó voltou.

- Vocês foram malvados com o homem cinzento - disse ela. - Mas ele tem um bom coração. Ele gostaria de conversar com você no bosque às doze horas.

- Ótimo, disse meu avô.

Eu estava batendo os dentes, mas eles não pareciam notar. Tudo parecia... normal.

Poucos minutos antes das doze horas, meu avô saiu. Nada poderia tê-lo impedido. Eu vi isso nos olhos dele. Minha avó e eu estávamos sozinhos. Os minutos passaram. Ela estava sentada lá, alta e severa, mas seus olhos brilhavam.

- Tá bom - disse ela. - Então vamos ver.

Eu estava engolindo. Eu bebi minha água. Desejei estar a mil milhas de distância daquele lugar horrível. O tempo passou. Não se ouvia um único som. Eu vi o gato morto na minha mente. Estremeci.

O tempo tinha se tornado uma hora. Então ouvimos passos lentos e hesitantes. Alguém se encostou na porta da frente e respirou pesadamente. Minha avó se levantou 
com a mesma expressão facial de antes. Ela abriu a porta. Meu avô estava parado ali. Sob a luz da lâmpada, eu podia ver que seu rosto tinha mudado. Os sulcos tinham se tornado mais profundos. Havia sombras escuras debaixo de seus olhos. A testa pingava suor, como se ele tivesse estado numa briga.

- Entre - disse minha avó. - Bem, o que disse o homem cinzento?

- O homem cinzento falou pela última vez - sibilou meu avô, entrando com grande esforço.

- Nils! - disse minha avó. - O que é que você fez?

- Nada.

- Você está com péssimo aspecto!

- Me custou.

Ele ficou em silêncio e se sentou pesadamente.

- Ele derrubou o boné da minha cabeça - disse ele.

Então, minha avó olhou para ele como se quase estivesse com medo.

- Preciso ir para a cama - disse meu avô. - Estou cansado. Mas, consegui.

$-\mathrm{O}$ quê?

- Provar! Eu provei que ele não existe. Ele não existe mais.

Com essas palavras, meu avô foi para a cama. Depois, minha avó e eu fomos para a cama também. Fiquei acordado por um longo tempo.

$\mathrm{Na}$ noite seguinte, minha avó saiu para sua caminhada habitual. Naquela vez, ao voltar ela parecia muito triste.

- Ele não estava lá - disse ela. - Nils! O que é que você fez?

Meu avô não respondeu.

Depois dessa noite, o silêncio engoliu a casa. Eu sofri por mais três dias. Depois disso, voltei para Malmö.

Uma semana depois, nossa campainha tocou. Meu pai abriu a porta.

- Bem-vindos, entrem!

Meus avós estavam ali. Meu avô falou.

- Tornou-se muito solitário lá. Podemos morar aqui por um tempo até encontramos um apartamento?

- Claro que podem!

- Tornou-se silencioso demais - disse meu avô. - Estranhamente silencioso. Tudo na casa ficou em silêncio. Eu não devia ter dito que ele não existia.

- Quem? - perguntou meu pai.

Eu sabia a resposta.

Meu avô suspirou.

- Eu realmente sinto falta dele. O homem cinzento. 
Então ouvi a voz da minha avó. Eu fiquei surpreso. Ela estava confortando o meu avô!

- Não fique triste, Nils - disse ela. - Há mais deles. Tenho certeza que existem muitos. Até aqui.

Eu estremeci.

- Mas não há nenhum como o nosso - meu avô disse com um ar triste. - Ele provavelmente tinha um bom coração, afinal. Eu só queria que ele não tivesse derrubado o boné da minha cabeça! 